\title{
Enemy love and the reinvention of identity
}

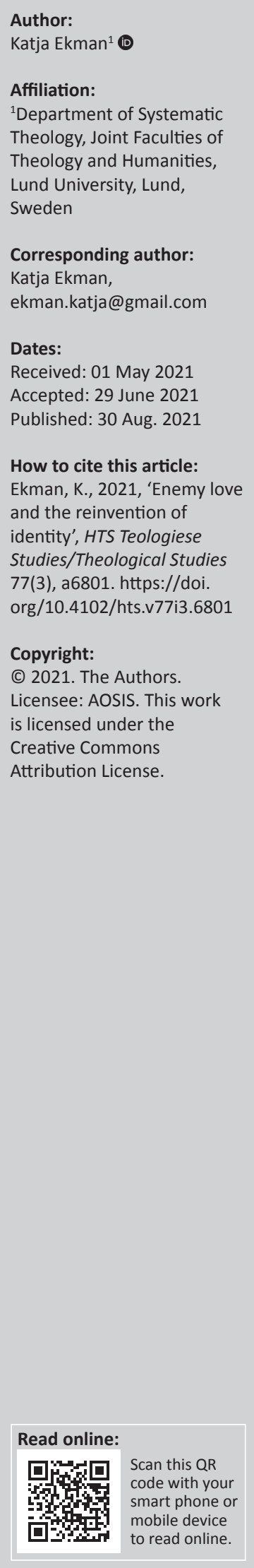

This article investigates the reception of Jesus' command to 'turn the other cheek' and 'love your enemies', as found in the Sermon on the Mount in Matthew 5:38-48, among Christian Palestinians. With the help of basic tools from the postcolonial discourse, structures of power, identity and subjectivity of these commands are examined. Although seeming to advocate a quiet acceptance of violence, the commands are interpreted as empowering calls to contribute to the transformation of the self, the other and the society. A person's dignity is seen to be restored and the transition from reactivity to agency is made possible. At the same time as the commandment of love ensures the uncompromising work for mutual respect and affirmation of both parties' humanness and creation in the image of God. Walter Wink helps to understand the logic of nonviolent resistance that the pericope is leading to in the eyes of the interviewees. In the last section, both the Bible text and the insights gained by the examination of its reception are condensed and further expanded by a theory of love inspired by Dorothee Sölle. This theory of love argues that love is not only a general approach to life, rather than a sentimental feeling, but the basic principle of life, the courage to continue to love where no reason or hope is left, just the will to remain and love into the void. This is interpreted to be the strongest kind of love and a tremendous empowerment in the reinvention of identity.

Contribution: This article contributes to the examination of identity processes within the field of theology and Bible interpretation as liberation and empowerment. The ethical and political relevancy of Scripture is here actualised in the example of the Palestinian context where questions of identity, justice and agency are more important than ever.

Keywords: enemy love; turn the other cheek; Palestine; nonviolent resistance; imago Dei; identity; dignity; theory of love; empowerment.

\section{Introduction}

In fall 2012, I conducted a fieldwork consisting of interviewing six Palestinian theologians on their understanding of Matthew 5:38-48, a pericope found within the Sermon on the Mount and including Jesus demand to 'turn the other cheek' and 'love your enemies'. ${ }^{1}$ Having previously lived in Bethlehem for 1 year in my young adult life, having experienced the checkpoints, the nightly intrusion of soldiers, the Palestinian peoples' cry for their land and striving for normal lives, I was well aware of the impossibility that these Bible verses present. For Palestinians, life under occupation means to suffer from harsh restrictions of movement and a constant insecurity rooted in the feeling of being at the mercy of the occupier. However, the most fatal impact of occupation is the lack of perspectives and the damage of the belief in future. And yet, the Christian Palestinian community cannot and does not want to neglect Matthew 5:23-48. Against all expectations, these verses, experienced as very challenging for people living under occupation, turned out to evoke a reinvention of identity and an empowerment to a moral and executive selfconfidence.

This article's aim is to give an insight into what I want to call practical exegesis on an existential ground. Jesus' demand of enemy love and turning the other cheek is not a hypothetical thought for Palestinian Christians. It raises questions of identity, of justice, of a God that seems to ask for acceptance of personal and communal tragedies. Here, I will investigate both the Bible text's message and my interviewees' reception of it, with special focus on the question of identity and the identity-transforming power that can be found within it. I will, with the help of my interviewees and theologians - Walter Wink and Dorothee Sölle, develop a theory of love, an approach that aims to maintain one's own and the other's dignity, and leads from re-action to the possibility of action. Below, one will find a brief methodological section which provides an insight in how I

1.A transcription of the recorded interviews was made. All Bible quotations in English refer to the New Revised Standard Version. All Bible quotations in Greek refer to Novum Testamentum Greacum 27.

Note: Special Collection: New Landscapes in Identity: Theological, Ethical and Other Perspectives, sub-edited by John Klaasen (University of the Western Cape). 
conducted the study. Afterwards, I will start out with a short discussion of the Bible text and presentation of the theoretical framework, and continue to examine 'turn the other cheek' and 'love your enemy', to finally conclude with a discussion of the observed identity process and a theory of love.

The interviews were semi-structured and conducted in Bethlehem, Jerusalem and Ramallah, during a time span of 2 weeks. One person at a time was interviewed. The interviewees belonged to different Christian denominations, two were female and four were male, between 40 and 75 years of age. All the male participants were ordained; one of the female interviewee was the leader of her congregation. All of them contributed to the Kairos Palestine document, and all of them view their theological activity belonging to the field of liberation theology. This interpretation of scripture leads to a reading of the Bible that emphasises and elaborates its liberating power.

My questions were simple in their formulations: 'What does this text mean to you and the Palestinian Christian community? What is "love" and "the enemy", and how can one "turn the other cheek?"' The analysis of the interview transcript was made by a continuous returning to the Bible text and the experienced challenges it presented for the interviewees. Asking people living under occupation, with a very limited possibility to move freely or live - what many of us would call - 'normal lives' in peace, these questions, is to dive directly into their understanding of their own identity and ethics. As the method of semi-structured interviews permits, the interviewees and I were discussing the questions, which led us into new questions and fields of inquiry. My intention was to give as much space as possible to the interviewees during our conversations, but it would obviously be naïve to think that I and my questions, my way of presupposing that they are challenging ones, had no impact on this study.

\section{Theoretical remarks and the text}

As mentioned previously, this article focusses on the reception of Matthew 5:38-48 among contemporary Palestinian Christians living under the Israeli occupation. The circumstances under which the text of the Gospel was written were also witness of (Roman) occupation and politically and military control of the Jewish society in Palestine during the first century. Scholars have highlighted the importance and contribution of the perspectives of colonialism or postcolonialism within New Testament studies (cf. Leander 2011; Runesson 2011). I have chosen here to follow this line of thought as it provides this study with the tools of reflecting over structures of power, identity and subjectivity. One can argue that colonialism and occupation are not the same political structure. However, there are similarities that make the comparison worthwhile. As the literary scholar Loomba (2005:11) states, colonialism can be seen 'as the takeover of territory, appropriation of material resources, exploitation of labour and interference with political and cultural structures of another territory or nation'. This definition surely reminds of the state of occupation. Even within the Palestinian theological discourse, this comparison is made (cf. Salguero 2011:220-225). ${ }^{2}$

Matthew 5:38-48 is, as mentioned, embroidered within the Sermon on the Mount and belongs to the six antitheses (where the present pericope accounts for the two last antitheses) that are structured in a similar pattern: the

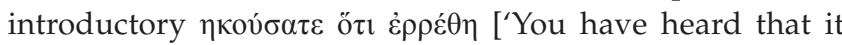
was said'] and the expanding of the cited law by $\dot{\varepsilon} \gamma \omega \grave{\delta} \delta \dot{\varepsilon} \lambda \dot{\varepsilon} \gamma \omega$

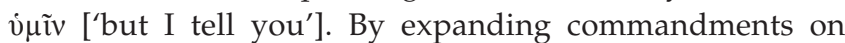
moral and social righteousness, Jesus is bringing forth his teachings about the beginning and coming of Kingdom of Heaven, in the light of which his speech has to be interpreted (cf. Piper 1991:69).

For both the text itself and the reception of my interviewees, it is important to stress its genre. The Sermon on the Mount reflects the Jewish tradition of the Aggadah as moral exhortation, at times striving after perfection. (As verse 48 exemplifies: 'Be perfect, therefore, as your heavenly father is perfect'.) As Heschel (1994:336f.) explains, 'Agada deals with man's ineffable relations to God, to other men, and to the world'.

In the first section of the pericope, this becomes clear when the issue of retaliation is addressed. The text seems to advocate not only to refrain from retaliating equal with equal, but offer even more subordination, as verses 39-41 show. Verse 41, for example, alludes to the Roman practice of a Roman soldier forcing somebody to walk a mile (Latin mille) with him, carrying his belongings (cf. Davies \& Allison 1988:547). If you are forced to do this, walk one more mile with him, so our text. When it comes to 'turn the other cheek', some remarks should be made. 'But if anyone strikes you on your right cheek, turn the other also' (v. 39). If one would want to slap somebody on the right cheek, as indicated in the text, one would have to use his/her left hand or the back of the right hand. Then as now, a majority of human beings were right-handed, so it would be more natural that the cheek that is hit is the left one. Even today, the left hand is seen as the unclean hand in the Middle East and large parts of Asia, so hitting somebody with the left hand would, besides being much less powerful, be to treat the other as dirt. To slap with the back of the hand, on the other side, was used to hit others that were below one's own social status, like slaves, children and women (cf. Davies \& Allison 1988:541f.; Wink 1992a:176). Rather than to harm physically, the situation the Gospel speaks about seems to address the question of personal rights, justice and dignity. To turn the other cheek and to go as far as to love the enemy is undoubtedly to break this chain of violence, but, as it seems, at a very high cost - a question my interviewees struggled with.

2.For further reading on theology in the Palestinian context please see the excellent works of Zaru (2008); Raheb (2014); Ateek (2017) and Khoury et al. (eds. 2019) among others. In the following, I chose to concentrate on the Palestinian voices among others. In the following, I chose to concentrate on the Palestinian voices
mainly through my unique interview material, as the books mentioned are wellknown and easily accessible. 


\section{Turn the other cheek}

As I have just shown, to turn the other cheek does not seem to encourage the continuation of physical injury. Let us now turn to a possible and probable answer to the question of how these verses can be interpreted, and what the application of them in life can mean.

Many interviewees state that their first look at Matthew 5:3848 made them lose hope, as one of them summarises: 'But if I accept violence, turn the other cheek, that's violating who I $\mathrm{am}^{\prime}$. To not fight back, to not retaliate, is primarily understood as to eliminate every possibility of the articulation of one's own needs and personhood. My interviewees could all identify with the person who is being hit and asked to turn the other cheek in the text, meaning the victim.

To understand oneself as a victim is to see oneself as passive, surrendered to the power of, and at the mercy of 'the other'. Postcolonial theory helps to uncover how structures of power seem to cement societal oppressive forms: 'human beings internalize the system of repression and reproduce them by conforming to certain ideas of what is normal and what is deviant' (Loomba 2005:40). Thus, when expressing that acceptance of violence would implicate a violation of one's own identity, as mentioned above by my interviewee, an important step within the process of an alternation of identity is made. One is not willing to surrender and to accept the status of a victim that one was designated. There still remains the question of what to do with the Bible verse of turning the other cheek, without being forced to interpret it 'like somebody driving drunk and you tell him: "Give some more gas!"'

As has been outlaid in reference to the Biblical text, the violation seems to address mainly the victim's dignity and identity. However, the reaction Jesus is advocating, to turn the other cheek, implies a restoration of this dignity and a reinvention of identity. The interviewees elaborated an understanding of the verse that focusses on Jesus' command to adopt a different behaviour than that which 'is driven by vengeance, by instinct, by reaction'. After having been hit on the right cheek (with the 'unclean' left hand or the insulting back of the hand), the victim is changing the arena of the social encounter by offering the left cheek (to be hit with the right and stronger hand), saying: 'Hit me one more time, but this time, as your equal'. No violence is used, and yet the victim is forcing the perpetrator to look at him or her as an equal human being. The personhood is regained by this step; from a solemnly reactive behaviour to an active, plot-driving way of acting. As Kim (2020:598) states in her article on postcolonialism and theological intersectionality, '[i]nstilling agency is a crucial step in reclaiming one's identity and one's future'. Suddenly, the one who has been the passive victim can discover different alternatives of action. One interviewee formulates this similarly in relation to the text: 'Jesus invites to movement, not to resignation'. The transition from reactivity to activity and agency is the first of the many possibilities the pericope provides the reader with.
Further, the interviewees saw the Bible text not only leading to a change in their own behaviour, but also as an incitement for 'the other' to change. By turning the other cheek or walking the second, extra mile, 'you are triggering something that the enemy is not anticipating' and the circumstances are set a new, forcing the enemy to 'look at [you] as an equal ... human being with dignity'. One interviewee even expressed that the question of who is the victim is addressed in a new light: 'I no longer am humiliated [by soldiers at the checkpoint] because I believe that the soldier is humiliating himself or herself'. To turn the other cheek and thereby astonishing the oppressing part is, thus, an activity that was referred to as 'awakening' of 'the other', following upon the awakening of the self. The text is interpreted as a confrontation of the other' with his or her behaviour, and the absurdity conveyed by it. If you are forced to give your coat but you choose to give your undergarment away as well, your counterpart has to look at you being naked, which was a great taboo (see Wink 1992b:202). Yet, it is also meant to appeal to his or her humanity and shame: Look what you do to me. At the same time, a clear message of lost supremacy is given: Your power over me is about to get lost. As Wink and Wink (1993:374) put it, ' $[t]$ he dominator is forced to come to terms with the humanity of the other as he is no longer protected by the story of his "rightful" position'. Jesus' teaching is not seen as an instruction for certain circumstances but goes beyond situational behaviour towards a general ethical approach (cf. Ateek 1989:95-96). This general approach is summed up and concentrated in the second commandment of the text, the love of the enemy.

\section{Love your enemy}

If to turn the other cheek is understood to be difficult, to love one's enemy is even harder, as it dictates one's feelings and inner attitude towards someone or something conceived as deeply negative. As one of my interviewees honestly states, '[i]t is very difficult to love someone who is aggressing you. We can't preach love to our people, to tell you the truth'. Once more, the text is confronting the reader with its seemingly impossible demands. The text's Sitz in the Aggadah tradition becomes mercilessly clear. My aim here is not to interpret this tension away. Love is not the soothing principle that is just making everything fine. But it can, examined from another angle, give different perspectives on the reality of my interviewees and function as a principle that motivates to nonviolent activity that the interviewees strive after and that is not merely a reaction to experienced violence. They try to follow, as The Expositor's Bible Commentary states, Jesus' call to his disciples 'to become what they not yet are' (eds. Longman \& Garland 2010:193).

There is a painting on the separation wall that Israel has built, near the big check-point in Bethlehem, saying With Love and Kisses: Nothing Lasts Forever. It is a clear message to the Israeli government that this too shall pass. The allusion to love and kisses sounds like love is all about hearts and flowers. Of course, the cynicism is not lost on anyone passing by and reading it. It becomes clear that, to love one's enemy, love 
needs to mean something more than hearts and flowers. As Burridge (2007:54) states, "love" means something tougher than many ideas of "the loving thing to do."' He argues that Jesus' understanding of love is deeply connected to 'how he both strengthens and relaxes the law in an eschatological context' (Burridge 2007). In both antitheses that are discussed here, the law is extended even further. First, the lex talionis, as we have seen in the previous section, and now even the wellknown commandment to love one's neighbour, which was seen to apply mainly to people in one's direct nearness (cf. Piper 1991:91). To love one's enemy, then, is a truly divine action, following Jesus' call for perfection, an action that Eduard Lohse, cited by Burridge (2007:55), calls 'the radicalisation of the love commandment'. My interviewees drew a sharp line between the every-day understanding of love and the love Jesus is asking for. They define it as 'real affective costly Christian love' and conclude that '[love] is not a sudden automatic thing' but something that is 'built when there is respect for everyone ... so maybe the respect turns into love because you care'. It is clearly a love that has to be worked for and that by no means is for free.

The Palestinian Christians I spoke to link enemy love, being rooted in respect, uncompromisingly to every human's partaking in the imago Dei. Seeing the other as created in and reflecting the image of God connects the other and the self with each other in mutual responsibility. This basic approach towards life is what is seen to be summarised in Jesus' use of love. Love then is not merely sentimental, but its emphasis lies on the will to recognise the self's and the other's dignity. As Cesaire Aimée states, cited by Loomba (2005:24), structures of oppression can be discovered by their 'thingification' of human beings, which 'not only exploits but dehumanises and objectifies the colonised subject'. Further, when 'us' and 'the others' are understood as an almost hostile dichotomy, both parts are frequently depersonalised by a pluralisation (Loomba 2005:118) that lifts all the complexity of the process of mutual understanding from the parties' shoulders.

The love that is advocated here is objecting to all these mechanisms. It is not interested in the other remaining the alien other, but wants to 'include them so they opt out of the structure'. The enemy that the Bible text speaks about is not only perceived to be 'the other' as individual, but also as the system. 'Those people [the Israelis] are not necessarily only actors, they are also objects of the system', one interviewee explains. Even the enemy is a victim, as 'identity is set by the empire' for people on both sides. The only way to try to liberate oneself and the other from the system withholding one's own morality and not becoming a perpetrator is inclusion in the love that is based on the acknowledgement of the other's humanity:

'To be open to the other, to understand the other, to show compassion to the other, to help the other to get out of this hatred and injustice, that's love. That's why it is liberating for me.' (Autumn, 2012, T44)

One mission that the interviewees saw evoked by the text was the liberation of both sides, taking its starting point in love. This prevents from nurturing the system with further violence and hatred, something one of them described as 'the institutionalization of fear', that is fought by the exercise of love and thereby liberation: 'Liberation cannot be liberation if it brings enslavement to the other side. It has to be liberating for everyone'. The nonviolent action of turning the other cheek is directing liberation that has to happen within the paradigm of love, because ' $[w]$ ithout liberation for both, the system will simply continue to perpetuate domination' (Wink \& Wink 1993:371) This turning point is marked by the belief in love's transforming character. By encountering the enemy with love, the beginning of such transformation is made possible: 'love that transforms is the true kind of love, and this is what removes enemies from the formula'. Yet, this might sound natural and easy, but as the postcolonial discourse has shown, 'many resistance movements have had to struggle to transform, and not simply invert, existing discourses about race'. (Loomba 2005:106, italics in original) The same is applying to the Palestinian context, where my interviewees sought to transform both their self-perception, the perception of the other and the situation and the other's way of understanding him- or herself. As Kim (2020:597) puts it, 'the subaltern needs to create new ways of being'. To be able to bring about change, a creative transformation is needed. In true liberation theological spirit, Ateek (1989:20) states, 'the oppressed are not totally powerless. They have the power of truth and justice'. To not miss the mark, the nonviolent struggle needs to be embedded in the paradigm of love, as both truth and justice are truly powerful principles.

As has been mentioned earlier, the motivation of the interviewees to exercise both the turning of the other cheek and the love of the enemy lies in the fact that they see it as a way of actively changing the conditions they live under. Yet, many see an even deeper reason, namely the participation in the work for the Kingdom of Heaven, or as one interviewee says, in 'God's will on earth'. To do what Jesus commands, which also is what Jesus did and exemplified with his own life, is the imitation Dei (cf. Burridge 2007:224; Theissen 1979:51) and the imitatio Christi. Burridge (2007) argues that the gospels are ancient biographies, aimed to inspire rather than to be 'coherent ethical treatises':

Jesus' ethical teaching is not a separate and discrete set of moral maxims, but part of his proclamation of the kingdom of God as God's reign and sovereignty are recognized in the here and now. (p. 61)

It is exactly in this way the Palestinian Christians I interviewed interpreted the Bible text, following the call to strive after divine behaviour, having Christ as role model.

\section{A theory of love}

When speaking about love, one has to be careful. 'Love' is a word filled with a vast content and often directly affined with the word 'like'. As shown previously, 'love' in the command to love your enemies is not primarily meant to be understood 
as an emotional, sentimental way of showing affection. Love is an approach towards life, a decision that is taken by the subject to encounter every human being as the image of God, as subject of his or her own life with the power to agency. This is, as stated in an interview cited previously, costly. Wink (1992a) argues that it is a step worth taking despite of the hard work connected to it:

When anyone steps out of the system and tells the truth, lives the truth, that person enables everyone else to peer behind the curtain too. That person has shown everyone that it is possible to live within the truth, despite the repercussions. (p. 98)

The explosive power hidden in this love becomes clear.

Yet, a closer definition of this love is to be made. The German theologian Dorothee Sölle formulates thoughts about love in her reflections on suffering, referring to the Jewish philosopher Simone Weil. Neither for Sölle sentimental feelings are predominant within the paradigm of love, yet she keeps the affinity to emotions vivid.

To start with, her theology is based on the importance of the immanent:

God is not in Heaven, he is hanging at the cross. Love is not supernatural, intervening, self-asserting power - and to meditate the cross can mean to bid farewell to this dream. (Sölle 2018 [original 1973:171. All quotations of Sölle will be rendered in my translation])

In other words, love is to get your hands dirty. It is precisely the image of hands that Sölle uses to explain how (God's) love is realised, stating that 'God does not have any hands but ours' (Sölle 2018:171). Applying this to my example, enemy love might be a call for the imitation of God, but it is also the only way to exercise divine love: through human beings created in the image of God. However, love is not one feature of life, but a choice of an approach towards and the condition of life: 'The misfortune that deprives us of every possibility to carry on loving is that which destroys us the most' (Sölle 2018:178). When one cannot love anymore, one is dying spiritually, losing his or her belief in that there is a future, a morning that is worth getting up to. Yet, the happening of the cross is offering a possibility, not primarily because there is a resurrection (no one could expect that), but because it tells a story of remaining. As Sölle (2018) puts it:

[T] he only rescue for the human being in this state of despair lies in the continuation of loving (Weiterlieben), 'into the void', in a love to God that no longer is reactive, an answer to experienced luck, childish thankfulness, but an act that goes beyond all experiences. (p. 178)

To love into the void is to turn the other cheek and to love your enemy. It is, as Davies and Allison (1998:551) conclude, to love 'despite circumstances and results'. For my interviewees, these two aspects sum up together in the term of nonviolent resistance, which Wink and Wink (1993) sees as a means for transformation:
Nonviolence, or the recognition of the other's essential humanity, provides a methodology for transforming the current system without simply replicating it: it shows the promise of transcending the current paradigm. (p. 373)

The essential character of this enabling love shines through in Sölle's (2018) further remarks:

Does the soul in the night of despair not stop to love, 'into the void', so can the object of its love righteously be called 'God'. We can even speak of an eternal affirmation of life, which installs itself in the dark night of the cross. (p. 179)

To love into the void is this costly, divine love that the interviewees were trying to live. When one still loves, although there is no reason or possibility to love anymore, no hope to clasp on, the paradox of the night of the cross offers maybe not as much as meaning, but a vow to life. This vow is the adherence to compassion, as Sölle (2018) states:

As a way of thinking (Denkform) the Christian faith, the paradox remains necessary, not the experience that can be read out of nature and history. Credo, non video: I see injustice, destruction, meaningless suffering - I believe in justice, the coming liberation, the love that is happening in the night of the cross. But exactly this motiveless (grundlose) belief in compassion (Barmherzigkeit) is religion of the slaves. (p. 180)

Sölle takes up Nietzsche's term of the religion of the slaves and fills it with the content of compassion. Compassion, and through it the will to remain, to love into the void, is what the cross provided. It is not a defect, as Nietzsche's formulation assumes, it is a strength. It is the strength to turn the other cheek and to continue, understanding oneself to be one who is holding on to life, love and compassion.

\section{Summary}

I have in this article tried to show that the two commandments of Jesus to 'turn the other cheek' and 'love your enemy', located in the Sermon on the Mount, provide a fruitful way to transform one's inferior identity, stressing the humanity of both parties in a conflict. My departure point was the reception of the text, captured in my interviews with Palestinian Christian theologians, and their understanding and interpretation of Matthew 5:38-48. The discourse of colonialism or postcolonialism offered a theoretical toolbox, helping me to reflect questions of structure, power and identity.

The investigation showed that 'turning the other cheek' was not interpreted in a submissive pacifistic way, but was rather seen as an empowerment to take one's own and the other's dignity, subjectivity and humanity seriously. Instead of asking for more striking, the aim is to get 'the other' to rethink his or her actions and behaviour, confronting him or her with both parties' pure humanness. Even to love the enemy was understood to underline that every human being is created in the image of God. Love was not primarily perceived as a sentimental feeling, but rather an approach to life and 'the other', a will to always respect one's own and the other's 
dignity. Together, enemy love and the turning of the other cheek were interpreted as a partaking in a nonviolent struggle. Instead of the passivity that a first look at Matthew 5:38-48 may seem to suggest, the verses showed a great potential of helping 'the victims' to leave their role and create another identity that is based on agency rather than reactivity only. The one who has been an object can see the possibility to claim his or her subjectivity and help the perpetrator out of his or her destructive behaviour. This was found to be a helpful principle for life under occupation for my interviewees.

I concluded this article with a further examination of the concept of love with the help of the German theologian Dorothee Sölle. This showed that love is not only an approach, but also the affirmation of life. The will to continue to love in the dark night of the cross, a place where no hope is in sight, is to love into the void, an action (not reaction) that is the bravest among our human actions, and at the same time the only possibility if one wants to continue living. To love the enemy and turn the other cheek is to love into the void, holding on to the will of life for everyone, being prepared for rough path to walk on, daring to still expect despite experience telling one otherwise.

Finally, I agree with Richard Burridge when he in the dedication of Imitating Jesus writes about his South African friends 'who taught me that interpreting the Bible can be a matter of life or death - or even more important than that!' As I also tried to show, interpreting the Bible can be a matter of holding on to one's dignity, subjectivity and inner freedom, even if the outer freedom is endangered. Yet, it is clear that this is no quick-fix and nor the easy way guaranteeing a carefree life. It might more likely remind us of the opposite; that life is a struggle and that this pericope is one challenging voice in it, but a voice guiding its reader to always believe in one's own possibility to challenge, and maybe even change, oppressive structures.

Of course, there shimmers a certain naivety over the principle of love being the solution. I would not go as far as to say that is the solution, but it can be the beginning of a path that confidently leads to more justice and less violence. Yet, to everyone who thinks this proposition might be far too naïve: propose better visions! As far as I can argue now, I cannot see a paradigm free from naivety, from the hope that change is possible. Wink (1992a:276) is certainly right when he writes: 'Loving enemies is also a way of living in expectation of miracles'. And what other alternatives are there, in the middle of the dark night of the cross, than to continue loving?

One of my interviewees' statements will get the last word in this article. It is a testimony of choosing the rough path of love and seeing the hope that can grow while wandering it. 'This is the biggest success of my life: that I have brought up children who do not hate'.

\section{Acknowledgements}

The author wants to direct a special thanks to the six Palestinian Christians and theologians who let her take part in their knowledge and shared it with her in the interviews this study partially builds up on.

\section{Competing interests}

The author declares that she has no financial or personal relationships that may have inappropriately influenced her in writing this article.

\section{Author's contributions}

K.E. is the sole author of this article.

\section{Ethical considerations}

The interview study has been conducted according to Swedish law and was ethically approved by the Joint Faculties of Humanities and Theology at Lund University, Sweden.

All interviewees, who were adults and all but one public figure participated in the planned and semi-structured interviews in informed consent.

\section{Funding information}

This research received no specific grant from any funding agency in the public, commercial or not-for-profit sectors.

\section{Data availability}

Data sharing is not applicable to this article as no new data were created or analysed in this study.

\section{Disclaimer}

The views and opinions expressed in this article are those of the author and do not necessarily reflect the official policy or position of any affiliated agency of the author.

\section{References}

Ateek, N.S., 1989, Justice, and only justice: A Palestinian theology of liberation, Orbis Books, Maryknoll, NY.

Ateek, N.S., 2017, A Palestinian theology of liberation: The bible, justice, and the Palestine-Israel conflict, Orbis Books, Maryknoll, NY.

Burridge, R.A., 2007, Imitating Jesus: An inclusive approach to New Testament ethics, Eerdmans, Grand Rapids, MI.

Davies, W.D. \& Allison, D.C., 1988, A critical and exegetical commentary on the gospel according to Saint Matthew Vol. 1: Introduction and commentary on Matthew 1-VII, T.\& T. Clark, Edinburgh.

Heschel, A.J., 1994, God in search of man: A philosophy of Judaism, p. 16, Noonday Press, New York, NY

Khoury, R., Zimmer-Winkel, R. \& Sabbah, M. (eds.), 2019, Christian theology in the Palestinian context, Aphorism, Berlin.

Kim, G.J.-S., 2020, 'Postcolonial theology and intersectionality', Journal of Ecumenical Studies 55(4), 595-608. https://doi.org/10.1353/ecu.2020.0047

Leander, H., 2011, Discourses of empire: The gospel of Mark from a postcolonial perspective, Dissertation, Göteborgs universitet, Göteborg.

Longman, T. \& Garland, D.E. (red.), 2010, The expositor's bible commentary, p. 9, rev. edn., Matthew-Mark, Zondervan, Grand Rapids, MI.

Loomba, A., 2005, Colonialism/postcolonialism, Routledge, London. 
Piper, J., 1991, 'Love your enemies': Jesus' love command in the synoptic gospels and in the early Christian paraenesis: A history of the tradition and interpretation of its uses, Baker Book House, Grand Rapids, MI.

Raheb, M., 2014, Faith in the face of empire: The bible through Palestinian eyes, Orbis books, Maryknoll, NY.

Runesson, A., 2011, Exegesis in the making: Postcolonialism and New Testament studies, Brill, Leiden.

Salguero, G.A., 2011, 'Postcolonial theologies: Promise and challenge for the Middle East', in M. Raheb (ed.), The invention of history: A century of interplay between theology and politics in Palestine, Diyar Publisher, Bethlehem.

Sölle, D., 2018 [original 1973], Leiden: Annehmen und Widerstehen, Kreuz Verlag $\mathrm{GmbH}$, Hamburg.
Theissen, G., 1979, Studien zur Soziologie des Urchristentums: Wissenschaftliche Untersuchungen zum Neuen Testament 19, J.C.B. Mohr, Tübingen.

Wink, S.P. \& Wink, W., 1993, 'Domination, justice and the cult of violence', Saint Louis University Law Journal 38(2), 341-378, viewed 11 March 2021, from https:// search-ebscohost-com.ludwig.lub.lu.se/login.aspx?direct=true\&db=edshol\&AN= edshol.hein.journals.stlulj38.27\&site=eds-live\&scope=site.

Wink, W., 1992a, Engaging the powers: Discernment and resistance in world of domination, Fortress Press, Minneapolis, MN.

Wink, W., 1992b, 'Beyond just war and Pacifism: Jesus' nonviolent way', Review and Expositor: An International Baptist Journal 89(2), 197-214. https://doi. org/10.1177/003463739208900204

Zaru, J., 2008, Occupied with nonviolence: A Palestinian woman speaks, Fortress Press, Minneapolis, MN. 